\title{
KEBERSAMAAN DALAM PERBEDAAN: STUDI KASUS MASYARAKAT CIGUGUR, KABUPATEN KUNINGAN, JAWA BARAT
}

\author{
Syaripulloh \\ Fakultas Ilmu Tarbiyah dan Keguruan (FITK) UIN Syarif Hidayatullah Jakarta \\ Email: syarifibnuhasby@gmail.com
}

\begin{abstract}
This study was conducted to gain an overview of togetherness and barmony in the life of a multi-religious society Cigugur. The study was conducted using descriptive-qualitative methods deskriktif, with the observation, in-depth interviews, and documentation study as data collection techniques. The results showed that Cigugur people who have a diversity in religion, namely Islam, Christianity, Catholicism, Protestantism, Agama Djawa Sunda (ADS) can coexist peacefully. They can live together respectfully because they have strong blood ties. For the people together is more important than the divisions caused by differing views. The unifying factor is the chairman of each religion, in addition to the prominent role of Pangeran Djatikusumah as Madrais descent. As the dominant culture, Agama Djawa Sunda (ADS) implement a full tolerance for Cigugur society to embrace and practice religious.
\end{abstract}

Keywords: unity, diversity, Agama Djawa Sunda (ADS), the dominant culture

\begin{abstract}
Abstrak
Penelitian ini dilakukan untuk memperoleh gambaran tentang kebersamaan dan harmoni dalam kehidupan masyarakat Cigugur yang multi agama. Penelitian dilakukan dengan menggunakan metode deskriptif kualitatif, dengan observasi, wawancara mendalam, serta studi dokumentasi sebagai teknik pengumpulan datanya. Hasil penelitian menunjukkan bahwa masyarakat Cigugur yang memiliki keberagaman dalam memeluk agama, yakni Islam, Kristen Katolik, Kristen Protestan, dan Agama Djawa Sunda (ADS) dapat hidup berdampingan secara damai. Masyarakat saling menghargai karena memiliki ikatan darah yang kuat. Bagi masyarakat kebersamaan lebih penting daripada perpecahan yang ditimbulkan perbedaan pandangan. Adapun faktor pemersatu masyarakat Cigugur adalah ketua masing-masing agama, selain adanya peranan yang sangat menonjol dari Pangeran Djatikusumah sebagai keturunan Madrais. Sebagai budaya dominan, ADS menerapkan pola toleransi penuh bagi masyarakat Cigugur untuk memeluk dan menjalankan perintah agama.
\end{abstract}

Kata Kunci: kebersamaan, perbedaan, Agama Djawa Sunda (ADS), budaya dominan

\section{A. Pendahuluan}

\section{Latar Belakang}

Negara Indonesia adalah sebuah negara yang terdiri dari beraneka ragam masyarakat, suku bangsa, etnis, kelompok sosial, kepercayaan, agama, dan kebudayaan yang berbeda-beda dari daerah satu dengan daerah lain yang memperkaya khasanah budaya Indonesia. Keanekaragaman tersebut merupakan kekayaan dan aset yang sangat berharga. Namun, masih terdapat dampak negatif akibat dari keanekaragaman tersebut. Sebagai contoh adalah masih timbulnya konflik, baik antaragama maupun suku bangsa. Kasus yang menonjol adalah konflik antaretnis Madura dan Dayak di Kalimantan. Perbedaan agama menjadi salah satu pemicu terjadinya konflik di Ambon dan Sulawesi. Kedua konflik tersebut merupakan sebagian kasus bagaimana suatu perbedaan menimbulkan efek negatif.

Ketika perbedaan disikapi sebagai bencana, kehidupan masyarakat Indonesia mustahil mencapai kesatuan. Perbedaan pendapat 
antarindividu dapat menjadi musibah yang dapat memecah belah negeri. Dengan hal ini negara Indonesia tidak akan berjalan secara harmonis, selalu ada pihak yang merasa sebagai yang paling benar dan oleh karenanya kesepakatan tidak akan dapat diraih. Kebersamaan menjadi sesuatu yang utopis, mayoritas mendominasi minoritas dan sebaliknya minoritas dapat menguasai mayoritas. Konflik secara horizontal maupun vertikal dapat menghantui negeri ini setiap saat.

Sebagai bangsa yang multikultur, para leluhur sudah menyadari akan pentingnya saling menghormati dan saling menghargai antarsesama walau berbeda. Hal ini tercermin dalam semboyan negara kita "Bhinneka Tunggal Ika”. Sehingga, kebersamaan dalam perbedaan menjadi bagian yang harus tetap dipertahankan dalam kehidupan setiap individu di negeri ini. Kebersamaan dalam perbedaan dapat terwujud dengan sikap saling menghargai dan menghormati dalam kehidupan sosial. Perbedaan disikapi sebagai sebuah keniscayaan, bahkan bagian dari sunatullab (given). Manusia diciptakan oleh Tuhan untuk saling mengenal meski berbeda etnik, budaya bahkan agama.

Keberagaman di Indonesia merupakan akibat dari kondisi sosio-kultural maupun geografis yang begitu beragam dan luas. Kondisi geografis menempatkan Indonesia ke dalam negeri yang memiliki banyak pulau di mana setiap pulau dihuni oleh sekelompok manusia yang membentuk suatu masyarakat. Dari masyarakat tersebut terbentuklah sebuah kebudayaan mengenai masyarakat itu sendiri. Kebudayaan tersebut pastinya mengakibatkan keberagaman. Masing-masing masyarakat yang membentuk sebuah kebudayaan yang memiliki corak kebudayaannya sendiri.

Kebudayaan merupakan akar dari multikulturalisme. Multikulturalisme terdiri dari kata "multi" yang berarti plural dan kulturalisme yang berisi pengertian kultur atau budaya. Menurut Fay, sebagaimana dikutip Suparlan, multikulturalisme adalah sebuah ideologi yang mengakui dan mengagungkan perbedaan dalam kesederajatan, baik secara individual maupun secara kebudayaan. ${ }^{1}$

1 Parsudi Suparlan, "Menuju Masyarakat Indonesia yang Multikultural”. Antropologi Indonesia 69 tahun, 2002.
Dalam model multikultural, sebuah masyarakat (termasuk juga masyarakat bangsa seperti Indonesia) mempunyai sebuah kebudayaan yang berlaku umum dalam masyarakat tersebut yang coraknya seperti sebuah mosaik. Di dalam mosaik tercakup semua kebudayaan dari masyarakat yang lebih kecil. Mosaik tersebut membentuk masyarakat yang lebih besar dan mempunyai kebudayaan seperti mosaik itu. Model multikultural sebenarnya telah digunakan sebagai acuan oleh para pendiri bangsa Indonesia dalam mendesain apa yang dinamakan sebagai kebudayaan bangsa, sebagaimana yang terungkap dalam penjelasan Pasal 32 UUD 1945, yang berbunyi: "Kebudayaan bangsa (Indonesia) adalah puncak-puncak kebudayaan di daerah". ${ }^{2}$

Dalam menyikapi multikultural haruslah hati-hati, sebab multikultural dapat berkembang negatif ke arah hipermultikultural, dan caufinisme seperti menganggap budaya sendiri yang paling baik, upaya mencari nilai-nilai asli atau "indigenous culture" seperti misalnya penguasa Orde Baru yang banyak menggunakan bahasa Kawi dalam memberikan nama gedung DPR yang sulit dimengerti oleh orang biasa. Hipermultikultural yang lain adalah munculnya anggapan bahwa hanya penduduk asli yang dapat berbicara mengenai budayanya sendiri.

Menurut Parsudi Suparlan, membangun Indonesia yang multikultural hanya mungkin terwujud jika: (1) konsep multikultural menyebar luas dan dipahami arti pentingnya bagi bangsa Indonesia, serta adanya keinginan bangsa Indonesia pada tingkat nasional maupun lokal untuk mengadopsi dan menjadi pedoman hidupnya, (2) kesamaan pemahaman di antara para ahli mengenai makna multikultural dan bangunan konsep-konsep yang mendukungnya, dan (3) upaya-upaya yang dapat dilakukan untuk dapat mewujudkan cita-cita ini. ${ }^{3}$

Teori fungsional melihat kebudayaan sebagai suatu bentuk yang kompleks dari ide-ide, gagasan, nilai-nilai, norma-norma, peraturan dan sistem sosial yang terdiri dari aktivitas manusia yang berinteraksi, berhubungan serta bergaul satu dengan lainnya, setiap saat mengikuti polapola tertentu berdasarkan adat dan tata kelakuan,

$\begin{array}{ll}2 & \text { Ibid. } \\ 3 & \text { Ibid. }\end{array}$


bersifat konkret dan terjadi di sekeliling. Dalam hal ini kebudayaan menentukan situasi dan kondisi bertindak, mengatur dengan sistem sosial berada dalam batasan sarana dan tujuan, yang dibenarkan dan yang dilarang.

Kerukunan antarumat beragama di tengah keanekaragaman sosial dan budaya merupakan aset dalam kehidupan berbangsa dan bernegara di Indonesia. Dalam perjalanan sejarah bangsa, Pancasila telah teruji sebagai alternatif yang paling tepat untuk mempersatukan masyarakat Indonesia yang sangat majemuk. Pancasila adalah payung untuk memelihara eksistensi sosial bangsa.

Menurut Durkheim, ${ }^{4}$ masalah sentral dari eksistensi sosial adalah masalah keteraturan dan bagaimana mencapai solidaritas sosial dalam masyarakat. Durkheim membagi solidaritas dalam masyarakat menjadi mekanik dan organik. Solidaritas mekanik memiliki ciri pembagian kerja yang masih sederhana, cara hidup yang kurang bervariasi, karena kebutuhan para anggota masyarakat untuk memandang dunia juga kurang lebih sama, mereka memiliki aturan-aturan kolektif yang mengatur bagaimana berperilaku. Masyarakat ini terdapat dalam lingkungan pedesaan yang homogen. Sedangkan solidaritas organik memiliki ciri pembagian kerja yang sangat kompleks, hidup secara individual, ketergantungan terhadap teknologi, masyarakat ini lebih terbentuk di kota besar yang merupakan bagian dari masyarakat urban.

Masyarakat yang diteliti bukanlah bagian dari dua tipe solidaritas yang dikemukakan Durkheim, melainkan merupakan transisi dari masyarakat pedesaan ke masyarakat perkotaan. Selain itu masyarakat Cigugur, Kabupaten Kuningan, Provinsi Jawa Barat merupakan masyarakat multikultural dengan keanekaragaman agama. Sebagian penduduknya beragama Islam, sebagian lagi beragama Kristen Katolik, Protestan, dan di antara mereka ada juga yang menjadi penganut ajaran Sunda Wiwitan atau sering disebut Agama Djawa Sunda (ADS). Perbedaan yang terjadi di tengah masyarakat tidak menjadikan mereka harus pecah dan saling bermusuhan, karena bagi

4 J.A. Barnes, Durkheim's Division of Labour in Society, The Australian National University, Royal Anthropological Institute of Great Britain and Ireland, dalam http://www.jstor.org/stable/2796343, h. 163. mereka semuanya adalah saudara, semuanya beragama hanya caranya yang berbeda.

Berbeda dengan daerah lainnya di Indonesia, keberagaman dalam masyarakat Cigugur tidak pernah menimbulkan konflik yang berarti. Isu sara yang menjadi penyulut api perpecahan tak pernah terlihat. Masyarakat hidup dengan sikap toleransi yang mengesampingkan kepentingan pribadi dan golongan. Masyarakat saling menghargai satu sama lain. Puncak dari kebersamaan ini adalah perdamaian. Perdamaian yang terjadi merupakan hasil dari pola adaptasi masyarakat dalam menyesuaikan diri dengan kebudayaan. Masyarakat selalu bersikap konformis sehingga perilaku menyimpang dan tindakan kriminal menjadi sangat rendah.

Masyarakat sangat menjunjung tinggi khasanah budayanya. Setiap tahun masyarakat bekerja sama dalam sebuah acara adat, yaitu Seren Taun. Berbagai tokoh agama hadir untuk mensukseskan acara ini. Acara yang merupakan pesta panen ini kemudian menjadi daya tarik pariwisata di Cigugur. Bukan hanya menteri dan perwakilannya, Presiden Abdurahman Wahid juga pernah datang dan menyaksikan acara tersebut, begitu pula wisatawan asing tidak ketinggalan mengikuti acara demi acara Seren Taun tersebut. Acara ini dipusatkan di Paseban Tri Panca Tunggal yang menjadi pusat Agama Djawa Sunda (ADS).

Di masa penjajahan Belanda, pendudukan Jepang, Orde Lama, dan Orde Baru, Kyai Madrais sebagai tokoh aliran ini dan ajarannya yang bernama madraisme merupakan ajaran terlarang. Tetapi pada masa pemerintahan $\mathrm{K}$. H. Abdurahman Wahid atau Gus Dur ajaran ini diizinkan, inti sari ajaran ini mengedepankan penghayatan terhadap Tuhan Yang Maha Esa.

$$
\text { Menurut pemaparan Pangeran }
$$

Djatikusumah sebagai pemangku adat di Cigugur, kebudayaan di Cigugur merupakan asli dari ranah Sunda. Oleh karena itu Cigugur memiliki keterikatan dengan masyarakat adat lainnya di tataran Sunda. Masyarakat adat itu adalah: (1) Urang Kanekes atau masyarakat Baduy di Kabupaten Lebak Provinsi Banten, (2) masyarakat Kampung Naga di Kabupaten Tasikmalaya, (3) masyarakat Cikondang di Kabupaten Bandung, dan (4) masyarakat 
Kampung Mahmud juga di Kabupaten Bandung Jawa Barat. ${ }^{5}$

Atas dasar pemikiran tersebut, tema "Kebersamaan Dalam Perbedaan: Studi Kasus Masyarakat Cigugur Kabupaten Kuningan" menarik diteliti.

\section{Identifikasi Masalah}

Berdasarkan latar belakang tersebut, masalah penelitian ini dapat diidentifikasi sebagai berikut:

a. Wilayah ini menjadi tempat Cagar Budaya yangharus dijaga kelestariannya.

b. Masyarakatnya menganut kepercayaan yang beragam atau berbeda satu sama lain (penganut ajaran Agama Djawa Sunda/ADS, Islam, Katolik, Protestan, dan lainnya).

c. Sejak masa penjajahan, Orde Lama, dan Orde Baru, Madrais sebagai tokoh aliran ini, merupakan ajaran terlarang, tetapi pada masa pemerintahan K. H. Abdurahman Wahid atau Gus Dur ajaran madraisme dengan mengedepankan Agama Djawa Sunda menjadi sesuatu ajaran yang tidak terlarang.

d. Terdapat acara "Seren Taun" yang diadakansetahun sekaliyangdidalamnya dilakukan acara diskusi budaya, acara budaya dari berbagai komunitasnya (Baduy Banten, Cikondang Bandung, Kampung Mahmud Bandung, dan lain sebagainya), termasuk juga hiburan tradisional lainnya. Acara ini memiliki daya magis yang cukup besar terutama bagi wisatawan, baik lokal maupun manca negara, pejabat daerah maupun pusat, serta kalangan politikus, dan masyarakat kebanyakan.

\section{Rumusan Masalah}

Permasalahanyangdiangkatdalampenelitian ini adalah: "Bagaimanakah kebersamaan dapat terjalin di tengah perbedaan yang terjadi pada masyarakat Cigugur, Kabupaten Kuningan, Provinsi Jawa Barat?"

5 Wawancara dengan Pangeran Djatikusumah, 8 September 2013 di Paseban Tri Panca Tunggal, Cigugur, Kabupaten Kuningan, Jawa Barat.

\section{Tujuan Penelitian}

Adapun tujuan penelitian ini adalah mencari jawaban atas permasalahan yang diajukan, yakni untuk memperoleh gambaran tentang model toleransi yang dikembangkan di lingkungan masyarakat Cigugur, Kabupaten Kuningan, Propinsi Jawa Barat.

\section{B. Metodologi Penelitian}

Penelitian ini dilaksanakan di Kelurahan Cigugur, Kecamatan Cigugur, Kabupaten Kuningan, Provinsi Jawa Barat. Cigugur merupakan daerah yang memiliki iklim sejuk karena berada di kaki Gunung Ciremai, memiliki kebudayaan yang khas dibanding daerah lainnya. Masyarakat Cigugur memiliki keberagaman dalam beragama, namun tidak mengalami perpecahan dalam kehidupan bermasyarakat. Penelitian ini dilaksanakan terhitung sejak tanggal 5 Agustus 2013 sampai dengan 24 September 2013. Peneliti melakukan tiga kali kunjungan lapangan.

Dengan menggunakan metode penelitian deskriptif kualitatif, dimaksudkan penelitian ini dapat menjelaskan segala sesuatu yang sedang berlaku serta menginterpretasikan kondisikondisi yang ada dan sedang berlangsung.

Teknik pengumpulan data penelitian ini adalah dengan metode observasi, wawancara, dan studi dokumen.

Adapun yang diwawancarai dalam penelitian ini adalah tokoh dari masing-masing agama, yaitu: (1) Pangeran Djatikusumah sebagai wakil pihak Agama Djawa Sunda (ADS) yang sekaligus merupakan pemangku adat di Cigugur, (2) Ratu Dewi Kanti yang merupakan juru bicara pihak Agama Djawa Sunda (ADS) sekaligus anak bungsu Pangeran Djatikusumah dan Ratu Emma, (3) Pak Edri Purwanto dari pihak Pesantren al-Ihya sebagai wakil Muslim, (4) Pak Yayan sebagai wakil pihak Kristen Protestan, (5) Ibu Uum sebagai wakil dari pihak Kristen Katholik yang juga merupakan biarawati pada Gereja Katholik, dan (6) informan kunci, yaitu Pak Didik dan Ibu Uti sebagai tuan rumah pada saat peneliti menginap.

Pada intinya metode dokumenter adalah mencari data mengenai hal-hal yang berupa catatan, transkrip, buku, surat kabar, majalah, prasasti, notulen rapat, leger, agenda, dan 
sebagainya. ${ }^{6}$

Analisis data dilakukan dengan mengorganisasikan data, menjabarkannya ke dalam unit-unit, melakukan sintesis, menyusun ke dalam pola, memilih mana yang penting dan yang akan dipelajari, dan membuat kesimpulan yang dapat diceriterakan kepada orang lain.

Dengan melaksanakan wawancara mendalam dan observasi, peneliti memperoleh data primer. Data primer ini tidak dalam bentuk angka-angka yang dapat diproses dalam metode kuantitatif. Jenis data yang diperoleh dari penelitian ini adalah data kualitatif yang tidak berbentuk angka-angka. Sehingga penjabarannya dalam bentuk catatan lapangan (field notes).

Dari rumusan di atas, dapat diambil garis besar bahwa analisis data pertama-tama dimaksudkan untuk mengorganisasikan data. Data yang telah terkumpul dan terdiri dari catatan lapangan, komentar peneliti, gambar, foto, dokumen berupa laporan, biografi, dan sebagainya. Setelah data terkumpul dari lapangan, maka peneliti akan mengolah dan menganalisis data tersebut dengan menggunakan analisis secara deskriptif-kualitatif. Analisisdeskriptif kualitatif merupakan suatu teknik yang menggambarkan dan menginterpretasikan arti data-data yang telah terkumpul dengan memberikan perhatian dan merekam sebanyak mungkin aspek situasi yang diteliti pada saat itu, sehingga memperoleh gambaran secara umum dan menyeluruh tentang keadaan sebenarnya. Tujuan deskriptif kualitatif adalah untuk membuat deskripsi, gambaran atau lukisan secara sistematis, faktual dan akurat mengenai fakta-fakta, sifat-sifat serta hubungan antar fenomena yang diselidiki.

\section{Hasil Penelitian dan Pembahasan \\ 1. Latar Penelitian}

Kelurahan Cigugur, Kecamatan Cigugur, Kabupaten Kuningan, merupakan salah satu kelurahan yang lokasinya tidak jauh dari ibukota Kabupaten Kuningan, tepatnya sekitar 3,5 km arah Barat dari pusat pemerintahan Kabupaten Kuningan. Lokasinya berada di kaki Gunung Ciremai sisi Timur dengan ketinggian sekitar 2002 , h. 206
661 meter di atas permukaan laut, terletak pada koordinat $108^{\circ} 27^{\prime} 15^{\prime \prime}$ BT dan 5058'8' LS, luas wilayahnya adalah 300,15 hektar. Wilayah ini merupakan wilayah transisi antara kota dan desa serta berkembang menuju kawasan perkotaan.

Bentang alam Kelurahan Cigugur secara singkat sebagai beirkut. Sebelah utara merupakan dataran rendah dan sebagian kecil berbukit yang berfungsi sebagai lahan persawahan dan tanaman pangan. Sebelah timur merupakan dataran rendah berupa persawahan dan sebagian berupa perbukitan. Sebelah selatan merupakan dataran rendah persawahan. Sebelah barat merupakan dataran tinggi dan perbukitan yang difungsikan sebagai lahan peternakan dan perkebunan.

Keberadaannya yang berada pada ketinggian 661 meter di atas permukaan laut, menjadikan kawasan Cigugur beriklim sejuk dengan suhu rata-rata $18^{0}-28^{\circ}$ celcius dengan curah hujan rata-rata $2000-2500 \mathrm{~mm} /$ tahun. Musim penghujan jatuh antara bulan November hingga Mei dengan curah hujan tertinggi jatuh pada bulan Desember hingga Maret.

Jumlah penduduk kelurahan Cigugur berdasarkan data yang dimiliki oleh Kelurahan Cigugur per 31 Desember 2012 adalah sebagai berikut:

\section{a. Berdasarkan Jenis Kelamin}

Jumlah Kepala Keluarga (KK) sebanyak 2.413 KK. Berdasarkan jenis kelamin, tercatat jumlah penduduk laki-laki di Kelurahan Cigugur lebih banyak dari jumlah penduduk wanita sebagaimana tertera pada Tabel 1 berikut ini.

\section{Tabel 1}

Jumlah Penduduk kelurahan Cigugur,

Kecamatan Cigugur, Kabupaten Kuningan, Provinsi Jawa Barat

\begin{tabular}{|l|l|l|}
\hline No. & Jenis Kelamin & Jumlah Penduduk \\
\hline 1. & Laki-laki & 3.615 orang \\
\hline 2. & Perempuan & 3.469 orang \\
\hline & Jumlah & 1.84 orang \\
\hline
\end{tabular}

\section{b. Berdasarkan Kelompok Usia}

Berdasarkan kelompok usia, penduduk Cigugur terbanyak berada pada usia produktif, yaitu usia 16 s/d 44 tahun. Adapun angka kelahiran bayi cukup tinggi. Keseluruhan data penduduk Kelurahan Cigugur berdasarkan kelompok usia adalah sebagai berikut: 
Tabel 2

Persebaran penduduk Cigugur berdasarkan

usia
\begin{tabular}{|l|l|l|}
\hline No. & Kelompok Usia & Jumlah Penduduk \\
\hline 1. & Usia 0 s/ 3 3 tahun & 482 orang \\
\hline 2. & Usia 4 s/d 6 tahun & 356 orang \\
\hline 3. & Usia 7 s/d 12 tahun & 735 orang \\
\hline 4. & Usia 13 s/d 18 tahun & 332 orang \\
\hline 5. & Usia 16 s/d 44 tahun & 3.252 orang \\
\hline 6. & Usia 45 tahun ke atas & 1.958 orang \\
\hline
\end{tabular}

\section{c. Berdasarkan Agama}

Berbeda dengan daerah lainnya di Jawa Barat, kelurahan Cigugur memiliki keberagaman dalam segi agama, dengan agama Islam yang dominan dianut oleh masyarakat Cigugur. Sebagaimana Tabel 3 berikut ini:

Tabel 3

Persebaran penduduk Cigugur berdasarkan agama

\begin{tabular}{|l|l|l|}
\hline No. & Berdasarkan Agama & Jumlah Penduduk \\
\hline 1. & Islam & 4.075 orang \\
\hline 2. & Protestan & 195 orang \\
\hline 3. & Katholik & 2.620 orang \\
\hline 4. & Hindu & 6 orang \\
\hline 5. & Budha & 12 orang \\
\hline 6. & Kepercayaan (ADS) & 176 orang \\
\hline
\end{tabular}

\section{d. Berdasarkan Pendidikan}

Berdasarkan pendidikan, penduduk Kelurahan Cigugur tidak ada yang mengalami buta aksara. Banyak penduduk Kelurahan Cigugur yang telah menyadari pentingnya pendidikan hingga tingkat SLTA. Data kependudukan Kelurahan Cigugur berdasarkan tingkat pendidikan adalah sebagai berikut:

\section{Tabel 4}

Data penduduk Cigugur berdasarkan tingkat pendidikan

\begin{tabular}{|c|l|l|}
\hline No. & \multicolumn{1}{|c|}{ Berdasarkan Pendidikan } & \multicolumn{1}{c|}{$\begin{array}{c}\text { Jumlah } \\
\text { Penduduk }\end{array}$} \\
\hline 1. & Lulusan SD/Sederajat & 1.752 orang \\
\hline 2. & Lulusan SLTP/Sederajat & 773 orang \\
\hline 3. & Lulusan SLTA/Sederajat & 2.764 orang \\
\hline 4. & Lulusan Akademi/Universitas & 543 orang \\
\hline 5. & Buta Aksara (karena Lanjut Usia) & - \\
\hline
\end{tabular}

Jumlah sarana keagamaan di Kelurahan Cigugur berdasarkan data Kelurahan Cigugur pada akhir tahun 2012, adalah sebagai berikut:
Tabel 5

Jumlah Sarana keagamaan di kelurahan

Cigugur

\begin{tabular}{|c|l|c|}
\hline No. & \multicolumn{1}{|c|}{ Sarana Keagamaan } & Jumlah \\
\hline 1. & Masjid & 6 \\
\hline 2. & Langgar/Mushala & 9 \\
\hline 3. & Majelis Ta'lim & 15 \\
\hline 4. & TPA & 2 \\
\hline 5. & Pondok Pesantren & 1 \\
\hline 6. & Gereja & 2 \\
\hline
\end{tabular}

Sarana keagamaan di atas berdiri di tengah kawasan pemukiman penduduk. Berbagai pemeluk agama dapat menjalankan ibadah dengan damai. Suara azan dari mikrofon masjid maupun mushalla tetap terdengar di wilayah Cigugur. Begitu pula suara lonceng gereja tetap terdengar saat kebaktian akan dilaksanakan.

Sarana keagamaan lainnnya bagi pemeluk agama Islam adalah pondok pesantren. Sebagai pondok pesantren modern satu-satunya di Kelurahan Cigugur, Ponpes al-Ihya berdiri sejak tahun 1988. Ponpes al-Ihya didirikan oleh beberapa tokoh agama Islam dan masyarakat di Kelurahan Cigugur. Pondok pesantren ini bernaung di bawah Yayasan al-Ihya Kuningan (awalnya: Yayasan Islamic Centre al-Ihya Kuningan) yang berdiri pada tahun 1985.

Pelajar atau santri yang bersekolah di Pondok Pesantren Al-Ihya bukan hanya berasal dari Kelurahan Cigugur. Santri tersebut berasal dari berbagai daerah di Pulau Jawa, termasuk dari DKI Jakarta. Ponpes al-Ihya berafiliasi dengan MAN Cigugur, sebuah lembaga pendidikan menengah atas Islam yang letaknya berdekatan dengan Pondok Pesantren al-Ihya. Selain Pondok Pesantren al-Ihya dan MAN Cigugur, terdapat pula Perguruan Tinggi Islam satu-satunya di kawasan Cigugur, yang bernama Perguruan Tinggi Islam al-Ihya. Tidak jauh dari perguruan tinggi tersebut juga terdapat MTsN Model Cigugur.

Sarana keagamaan bagi pemeluk agama Kristen Protestan di Cigugur adalah Gereja Kristen Pasundan. Berdiri sejak tahun 1965, bersamaan dengan dibubarkannya Agama Djawa Sunda (ADS) di Kuningan. Para 
penganut Agama Djawa Sunda (ADS) tersebut di antaranya pindah keyakinan menjadi anggota jemaat Gereja Kristen Pasundan (GKP) Cirebon. Gereja Kristen Pasundan (GKP) Cirebon menjadi Gereja jemaat CigugurKuningan pada saat ini. Bahasa yang digunakan dalam setiap kebaktian adalah Bahasa Indonesia diselingi dengan Bahasa Sunda pada Minggu keempat. $^{7}$

Sarana ibadah bagi penganut agama Kristen Katolik adalah sebuah gereja yang bernama Gereja Kristus Raja-Paroki Cigugur. Gereja ini terletak persis di depan Rumah Sakit Sekar Kamulyan. Perkembangan penganut Kristen Katholik yang menjadi jemaat Gereja Kristus Raja-Paroki tidak terlepas dari peristiwa pelarangan ADS pada tahun 1964. Pangeran Tedjabuana Alibasa (Keturunan Pangeran Madrais) beserta keluarga menyatakan diri sebagai penganut agama Kristen Katholik. Setelah peristiwa itu, terjadi perpindahan masal penganut Agama Djawa Sunda (ADS) menjadi Katolik. Mulai saat itulah kegiatan gereja Katolik Kristus Raja-Paroki mulai berkembang.

Terdapat satu bangunan di kawasan Cigugur yang menjadi pusat Agama Djawa Sunda (ADS). Gedung ini bernama Paseban Tri Panca Tunggal yang telah diakui sebagai Cagar Budaya Nasional pada tanggal 14 Desember 1976. Sebagai sebuah Cagar Budaya Nasional, Paseban Tri Panca Tunggal juga sering disebut sebagai keraton yang berada di Cigugur. Nama Paseban sendiri adalah tempat berkumpul dan bersyukur dalam melaksanakan ketunggalan selaku umat Gusti Hyang Widi Wasa. Kata tri bermakna tiga unsur, yaitu sir, rasa, dan pikir. Sedangkan panca atau lima bermakna lima unsur panca indra dalam menerima keagungan Tuhan Yang Maha Tunggal (Esa). ${ }^{8}$

\section{Kebersamaan di Tengah Masyarakat}

Masyarakat Cigugur merupakan masyarakat yang multi agama namun kehidupan mereka berjalan secara harmonis dan tidak ada konflik. Kedamaian dan kebersamaan begitu terasa mewarnai kehidupan mereka yang beragam keyakinan. Gotong royong dan kerja sama

Wawancara dengan Yayan Heryanto, S.Si (seorang Pendeta Kristen Protestan) pada tanggal 15 September 2013 di Gereja Kristen Pasundan (GKP) Cigugur, Kuningan Jawa Barat.

8 Artikel Cagar Budaya Nasional Gedung Paseban Tri Panca Tunggal. tetap terjalin dalam keseharian tanpa melihat perbedaan yang terjadi di antara mereka. Kesemuanyaitu didasarkan atas dasar persamaan hak sebagai warga dan rasa saling menghormati serta saling menghargai atas setiap perbedaan.

Berkenaan dengan kehidupan kemasyarakatan di Cigugur, Didi (warga Cigugur penganut kepercayaan Agama Djawa Sunda (ADS) mengungkapkan bahwa "dalam berbagai kegiatan sosial kemasyarakatan masyarakat Cigugur selalu bekerja sama dan tidak membedakan latar belakang agama dan kepercayaan mereka. Pada saat peringatan hari besar keagamaan apa pun semua anggota keluarga akan saling membantu walau mereka berlainan agama dan kepercayaan. Pada saat Idul Fitri atau Idul Adha, kami semua berkumpul di tengah keluarga yang beragama Islam dan ikut serta dalam membantu persiapan serta ikut merayakannya. Hal yang sama juga terjadi pada saat Natal, semua anggota keluarga akan kumpul dan membantu persiapan perayaan Natal serta ikut merayakannya. Demikian pula ketika Seren Taun yang merupakan perayaan bagi warga penganut Agama Djawa Sunda (ADS), semua warga Cigugur terlibat dalam semua tahapan perayaan Seren Taun".

Hal senada diungkap oleh Yayan Heryanto (34 tahun, seorang pendeta) yang menjelaskan bahwa "kerjasama dan gotong royong terjalin di tempat ini walau mereka berbeda keyakinan. Bagi mereka agama atau kepercayaan tidak menjadi penghalang untuk bekerja sama, karena bagi mereka semua agama adalah sama, yaitu mengajarkan akan kebaikan. Keterlibatan pemeluk Kristen Protestan dalam acara Seren Taun adalah sebagai bagian dari warga Cigugur". Hal senada diungkapkan oleh Edri (Pengurus Yayasan al-Ihya), yang mengatakan kerja sama antarsesama warga dalam merayakan peringatan hari besar keagamaan terjadi karena mereka memiliki ikatan darah yang sama".

Berkenaan dengan toleransi antarumat beragama di Cigugur, Edri menjelaskan bahwa "Penghargaan warga nonmuslim terhadap warga muslim yang sedang berpuasa, di antara mereka tidak melakukan kegiatan makan minum sembarangan. Ketika ada yang melanggar, mereka akan ditegur oleh temannya sendiri dan menghentikan aktivitas tersebut. Para pedagang 
di depan sekolah mereka (di depan komplek Yayasan al-Ihya terdapat sekolah Katolik Yos Sudarso) saat bulan Ramadhan akan disuruh masuk ke dalam lingkungan sekolah tujuannya pasti agar anak-anak sekolah tidak makan dan minum sembarangan. Ketika lebaran, mereka datang berkunjung dan mengucapkan selamat Idul Fitri kepada masyarakat Muslim". Hal senada juga disampaikan oleh Yayan (pendeta) dan Didi (warga masyarakat Cigugur) yang mengungkapkan bahwa penghargaan dan penghormatan atas kepercayaan orang lain yang berbeda merupakan inti dari kebersamaan yang terjalin di tengah masyarakat Cigugur. Dalam menjalani kehidupan sosial kemasyarakatan perlu dikesampingkan perbedaan agama dan kepercayaan.

Kebersamaan di tengah perbedaan yang terjadi pada masyarakat Cigugur menurut Yayan (pendeta) "kuncinya adalah dihargainya wilayah adat. Masing-masing agama memiliki pemimpin yang menjadi tokoh kunci perdamaian. Tokoh masing-masing agama ini yang menjadikan budaya setempat tetap lestari”. Hal senada juga diungkapkan oleh Edri (pengurus Yayasan al-Ihya) yang mengemukakan besarnya pengaruh tokoh adat dan tokoh agama dalam upaya mempertahankan kebersamaan di tengah masyarakat Cigugur yang agama dan kepercayaannya beragam".

Berkenaan dengan perbedaan di tengah masyarakat Cigugur, Pangeran Djatikusumah (Pemangku Adat Cigugur) mengungkapkan bahwa "kesadaran beragama berdasarkan prinsip ketuhanan, kemanusiaan, dan kebangsaan. Umat beragama harus sadar menjadi manusia yang berbangsa. Kesadaran manusia berangkat dari insaniyah dan wathoniyah. Semua agama berada pada kesadaran itu. Kesadaran ilahi bersumber dari kesadaran pribadi. Manusia harus benarbenar menghayati kepercayaan terhadap Tuhan. Manusia sebenarnya dekat dengan Tuhan, tapi kebanyakan tidak mengetahui posisinya. Di masa penjajahan, Orde Lama, dan Orde Baru, Kyai Madrais sebagai tokoh aliran ini dianggap sebagai ajaran terlarang. Tetapi pada masa pemerintahan K. H. Abdurrahman Wahid atau Gus Dur ajaran ini diizinkan dan mengedepankan penghayatan terhadap Tuhan Yang Maha Esa.
Pada masyarakat Cigugur kebersamaan tidak hanya ketika hidup, ketika sudah meninggal pun dimakamkan pada lokasi yang sama bersatu dengan yang lain walau berbeda keyakinan". Keadaan yang unik ini terlihat pada salah satu lokasi pemakaman yang sudah ada sejak ratusan tahun. Di lokasi pemakaman ini terlihat berbagai simbol agama menjadi penanda keberagaman tersebut. Simbol tersebut juga menjadi penanda agama yang dianut masing-masing makam.

Berkenaan dengan pernikahan terutama yangberbeda keyakinan, Pangeran Djatikusumah menjelaskan "Ketika melaksanakan pernikahan dapat disesuaikan dengan agama yang dianut. Jika ada perbedaan, datanya dapat disesuaikan. Orang yang telah berkeluarga tidak boleh bercerai, tidak boleh berpoligami. Karena poligami dianggap sebagai hal yang haram hukumnya".

Beliau juga menjelaskan, bahwa dirinya memiliki delapan orang anak dan mereka memiliki keyakinan yang berbeda (Katolik, Islam, Protestan dan Sunda Wiwitan atau ADS). Selaku pemangku adat di Cigugur, beliau menganut kepercayaan Sunda Wiwitan atau ADS/Anak tertuanya yang perempuan beragama Kristen dan bahkan menjadi Pendeta Bethel di Cirebon. Anak keduanya yang lebih dikenal dengan sebutan Rama Anom merupakan calon penerus beliau dalam memimpin adat di Cigugur menganut kepercayaan Sunda Wiwitan. Sedangkan anak-anak yang lainnya ada yang Islam, Katolik, dan Sunda Wiwitan". Beliau melanjutkan, bahwa "pada masyarakat Sunda yang ada penganut Sunda Wimitan, kebersamaan di tengah perbedaan seperti di sini (di Cigugur, pen) juga terjadi seperti di Susuru, Panawangan Ciamis, di Garut, dan di Banten karena pada dasarnya manusia haruslah welas asih, undak usuk, tata karma, wiwaha yudha raga (perang terhadap raga) dengan budi bahasa dan budi daya yang dimilikinya".

Menurut Ratu Dewi Kanti (putri bungsu Pangeran Djatikusumah), "perbedaan keyakinan yang terjadi di keluarga kami tidak menjadikan kami terpecah. Kebersamaan tetap dijalin. Ketika Seren Taun semua keluarga berkumpul di sini, bahkan kakak yang pendeta seringkali membawa jamaahnya berkunjung ke sini”.

Penghormatan terhadap pemeluk agama 
lain dirasakan oleh peneliti, walaupun tuan rumah, keluarga Pak Didi adalah penganut kepercayaan Sunda Wiwitan atau ADS, namun mereka menerima peneliti dengan tangan terbuka dan memberi kesempatan yang luas kepada peneliti untuk melaksanakan perintah agama.

Berkenaan dengan kebersamaan dalam perayaan Seren Taun yang dilaksanakan setiap bulan Rayagung dalam penanggalan Jawa atau bulan Drulbijah, Didi (warga Cigugur dan Penganut ADS) mengemukakan bahwa kegiatan Seren Taun merupakan kegiatan adat yang melibatkan warga masyarakat Cigugur dari semua kalangan tanpa membedakan latar belakang agama mereka. Berkenaan dengan hal tersebut, Yayan (pendeta) mengungkapkan bahwa "ketika digelar rangkaian acara Seren Taun yang kebetulan bersamaan dengan kegiatan kebaktian, maka gereja akan merubah jam kebaktian disesuaikan dengan acara Seren Taun, biasanya digeser ke sore atau malam hari. Hal ini dikarenakan bagi mereka keterlibatan dalam kegiatan Seren Taun merupakan bentuk dari Ibadah".

Keberadaan tokoh agama dalam berbagai kegiatan yang melibatkan masyarakat merupakan hal yang penting karena merupakan simbol keagamaan dan menggambarkan kebersamaan di tengah keberagaman. Yayan (pendeta) menjelaskan, "Jika ada tokoh agama atau adat belum hadir, acara tidak akan dimulai. Sebagai contoh, suatu hari dirinya berada di Cirebon untuk mengurusi urusan gereja, pada waktu yang sama terdapat acara di Cigugur dan mengharapkan kehadirannya. Walau sudah memberitahukan bahwa akan terlambat hadir dan mempersilahkan acara dimulai, namun kehadirannya tetap ditunggu dan acara tidak dimulai sebelum dirinya datang. Peristiwa ini membuat malu, dan berusaha untuk tidak mengulang keterlambatan pada acara adat".

Kondisi berbeda tampak pada pesantren, menurut Edri (pengurus Yayasan al-Ihya) "Pada acara Seren Taun, kami secara kelembagaan tidak terlibat dan melibatkan diri karena dalam Islam hal ini dapat dikategorikan sebagai syirik. Kepada para santri dan siswa yang sebagian besar pendatang dari luar Cigugur kami menjelaskan tentang kegiatan tersebut agar mereka memahami budaya setempat namun tidak diperkenankan mengikuti rangkaian acara. Secara khusus, yayasan juga tidak pernah diundang kalau pun diundang biasanya individu pengurus pada saat diselenggarakannya do'a bersama lintas agama”.

Menurut pemaparan Pangeran Djatikusumah sebagai pemangku adat di Cigugur, kebudayaan di Cigugur merupakan asli dari tanah Sunda. Oleh karena itu Cigugur memiliki keterikatan dengan masyarakat adat lainnya di tatar Sunda. Masyarakat adat itu adalah: (1) urang Kanekes atau masyarakat Baduy di kabupaten Lebak provinsi Banten, (2) masyarakat Kampung Naga di Kabupaten Tasikmalaya, (3) masyarakat Cikondang di Kabupaten Garut, dan (4) masyarakat Kampung Mahmud di Kabupaten Bandung, Jawa Barat.

\section{Penyesuaian dengan Lingkungan}

Tidak jauh dari Rumah Sakit Sekar Kawaluyaan Cigugur, sebuah rumah sakit yang dikelola oleh Yayasan Katolik, terdapat Gereja Katholik. Menurut Ignas (pemuda Katholik aktifis gereja), "Secara fisik bangunan dan peralatan atau perangkat ritual yang dimilikinya tidak jauh berbeda dengan gereja-gereja Katolik lainnya, namun yang membedakan gereja ini dengan gereja katholik di kota adalah ketika ritual keagamaan, yaitu lantunan doa-doa pujian tidak diiringi oleh piano layaknya di gereja Katholik di kota, namun diiringi oleh perangkat gamelan Sunda”.

Kondisi yang sama juga terjadi pada gereja Protestan, menurut Yayan (pendeta), "Sebagai bentuk penyesuaian diri dengan lingkungan, maka kami tiap minggu terakhir tiap bulannya melakukan kebaktian dengan gaya Sunda. Jamaah yang hadir harus berpakaian adat Sunda, demikian pula kita selaku pengurus juga berpakaian adat Sunda. Sedangkan khotbah dan puji-pujian dilakukan dengan menggunakan bahasa Sunda dan diiringi oleh gamelan Sunda. Pada minggu-minggu yang lainnya kegiatan kebaktian dilakukan dengan menggunakan bahasa Indonesia dan doa-doa pujian juga diiringi oleh perangkat musik modern (keyboard)". Ketika ditanya mengapa demikian, Yayan menjelaskan bahwa "Jika dilakukan tiap kebaktian dengan menggunakan bahasa Sunda 
dan diiringi oleh musik tradisional Sunda tidak memungkinkan karena diperlukan jumlah pemain degung yang cukup banyak, sedangkan jemaah sedikit bisa-bisa semua jamaah jadi pemain degung".

Secaraindividu, Yayan (pendeta) menyatakan bahwa "setelah mempelajari dan mendalami Ajaran Spritual ADS / Sunda Wiwitan dan membandingkan dengan Kitab Suci kami, saya berpendapat bahwa dalam beberapa sisi ajaran ADS/ Sunda Wiwitan mempunyai kemiripan dengan ajaran Kristen. Menurut saya, Kristen yang masuk ke Indonesia harus menyesuaikan diri dengan lingkungan setempat harus mau memutuskan menjadi Kristen Pribumi bukan Kristen Eropa yang dibawa masuk oleh para penjajah. Kondisi ini mendorong untuk tidak memiliki perasaan paling benar sendiri. Ajaranajaran lokal perlu dihargai agar dapat diterima oleh masyarakat mayoritas dan tidak terjadi pergesekan di tengah masyarakat".

Berkenaan proses penyesuaian diri dengan lingkungan, Edri (Pengurus Yayasan Al-Ihya) mengungkapkan bahwa "pada dasarnya kami berupaya untuk baik kepada siapa pun, bekerja sama dan saling menolong. Hal ini tampak pada berbagai kegiatan atau acara yang dilakukan masyarakat. Pada saat orang muslim mempunyai hajat, maka semua warga berkumpul namun mereka yang berasal dari luar muslim akan mengelompokkan diri dan tidak mengikuti ritual keagamaan, demikian pula sebaliknya saat orang non muslim yang mempunyai hajat maka orangorang muslim akan diberi tahu mana yang boleh dimakan dan mana yang tidak. Selain itu kami juga menjelaskan kepada santri-santri kami akan perbedaan yang terjadi di tengah masyarakat Cigugur, tujuannya agar mereka mengetahui dan dapat menyesuaikan diri dengan lingkungan setempat". Selanjutnya, Edri menjelaskan bahwa "posisi kami dalam kegiatan Seren Taun secara kelembagaan tidak berpartisipasi, namun kami menghormati kegiatan tersebut sebagai kegiatan atau acara adat".

\section{Kebersamaan dalam Perbedaan}

Robert W. Hefner menyatakan bahwa pada awalnya banyak ilmuwan yang yakin bahwa sistem demokrasi tak dapat berkembang di negara plural. Beberapa masalah yang dihadapi oleh proses demokratisasi adalah pluralitas masyarakat yang sangat kental. Sebagai sebuah negara majemuk yang terdiri dari ratusan suku bangsa dan berbagai kepercayaan, Indonesia menjadi negera yang memiliki peluang konflik yang besar. Konflik tersebut berasal dari sentimen keagamaan atau sifat caufinisme yang berlebihan.

Hefner mengutip pendapat Samuel P. Huntington, bahwa integrasi nasional membutuhkan penggantian sejumlah besar otoritas politik tradisional, agama, keluarga, dan etnis. Mengutip pendapat Furnivall, Hefner menjelaskan bahwa masyarakat majemuk adalah masyarakat yang terdiri dari dua atau lebih elemen atau tatanan sosial yang hidup berdampingan tanpa pembauran dalam satu unit politik. Furnivall percaya bahwa etnis dan agama merupakan bagian yang membentuk masyarakat begitu berbeda satu sama lain. ${ }^{9}$

Berpuluh tahun lewat Indonesia telah diguncang oleh berbagai kekerasan etnoreligius. Berbagai peristiwa terkait hal tersebut terjadi antara tahun 1996 hingga 2001. Sebagai negara yang mayoritas beragama muslim, corak keberagamaan dan toleransi sering tidak ditemukan pada beberapa wilayah justru yang dihuni kebanyakan non-muslim. Di situ isu sara merebak dan tak ayal korban jiwa pun berjatuhan dengan maksud penunjukan jati diri suatu agama maupun etnis untuk tetap eksis dalam kehidupan bermasyarakat.

Berdasarkan uraian tersebut, masyarakat Cigugur merupakan masyarakat yang multi agama, namun mereka tetap dapat bersatu dan bekerja sama dalam membangun daerahnya. Perbedaan keyakinan tidak menjadi kendala dalam menjalani kehidupan sehari-hari. Apa yang disampaikan oleh Didi (warga Cigugur dan penganut ajaran Sunda Wiwitan/ADS), Yayan (pendeta di Gereja Kristen Protestan Cigugur), Edri (pengurus Yayasan l-Ihya), serta Pangeran Djatikusumah (pemangku adat di Cigugur) menunjukkan kebersamaan yang dijalin bukan didasarkan atas kesamaan keyakinan, namun lebih pada kesamaan pandangan dan keturunan (kekerabatan). Kondisi ini sesuai dengan apa yang disampaikan oleh Suparlan

9 Robert W. Hefner, Introduction:Multiculturalism and Citizenship in Malaysia, Singapore, and Indonesia dalam The Politic of Multiculturalism: Pluralism and Citizenship in Malaysia, Singapore, and Indonesia, 2001, h. 4. 
yang mengungkapkan bahwa kesukubangsaan mempunyai efektivitas kekuatan sosial dalam batas-batas sesama anggota suku bangsa, sedangkan keyakinan keagamaan mempunyai jangkauan solidaritas sosial hanya dalam salah satu segmen masyarakat suku bangsa, dalam sesuatu masyarakat suku bangsa, atau di luar batas-batas sesuatu masyarakat suku bangsa. ${ }^{10}$ Karena itu, di satu sisi, keyakinan keagamaan dapat memperkuat atau memperlemah kekuatan sosial dari kesukubangsaan, sedangkan di sisi lain kesukubangsaan dapat tunduk dan berada di bawah bayang-bayang kekuatan keyakinan keagamaan.

Pada kasus masyarakat Cigugur tampak bahwa ikatan darah atau kekeluargaan mempunyai jangkauan solidaritas yang tinggi dibanding keyakinan keagamaan. Hal ini tampak dari diabaikannya perbedaan keyakinan keagamaan dalam menjalani kehidupan sosial kemasyarakatan. Hukum pertemanan, prinsip solidaritas, saling bantu, saling merasakan, dan sebagainya, hal inilah yang menjadi inti dari hubungan kekeluargaan. Semangat kekeluargaan adalah semangat nilai hubungan sosial antara sesama anggota keluarga, semangat persaudaraan, solidaritas antara sesama kerabat, semangat kolektivisme, dan semangat komunalisme. Sikap saling menghargai terhadap kebudayaan yang didukung oleh masyarakat lain, di mana masing-masing mengakui kelemahankelemahannya, kelebihan-kelebihannya, akan mendekatkan masyarakat-masyarakat yang menjadi pendukung kebudayaan-kebudayaan tersebut. ${ }^{11}$ Kondisi ini akan mendorong munculnya solidaritas dalam kelompok. Menurut Garna dalam Arkamudin, solidaritas merupakan bentuk kekuatan persatuan internal suatu kelompok, kekuatan internal tersebut berupa suatu kepatuhan bersama yang didasari oleh ikatan tali persaudaraan dan ikatan daerah. ${ }^{12}$

Proses penyesuaian diri dengan lingkungan dilakukan para pendatang di mana pun, termasuk di Cigugur. Pendatang berupaya menyesuaikan diri agar dapat diterima oleh kelompok mayoritas.

\footnotetext{
10 Parsudi Suparlan, "Menuju Masyarakat Indonesia yan Multikultural”. Antropologi Indonesia 69 tahun, 2002.

11 Soerjono Soekanto, Sosiologi Suatu Pengantar, Jakarta: Rajawali Press, 2006. h. 71.

12 Arkanudin, Hubungan Sosial dalam Masyarakat dalam http:// prof-arkan.blogspot.com/ 2012/04/hubungan-sosial-dalam-masyarakat.html. [Tersedia: 22-11-2012]
}

Kondisi ini dikarenakan Dominasi budaya dominan di tengah masyarakat menjadikan para pendatang berupaya menyesuaikan diri dengan kebudayaan setempat. Tujuan penyesuaian diri tersebut, adalah agar keberadaan mereka yang minoritas dapat diterima oleh lingkungan budaya mayoritas, karena Komunitas dan masyarakat setempat yang mayoritas dan dominan menekankan penggunaaan prinsip "di mana bumi dipijak langit dijunjung” sebagai acuan yang harus dijadikan pedoman oleh para pendatang. ${ }^{13}$

Proses penyesuaian diri tampak pada kegiatan yang dilakukan gereja Protestan, seperti diungkapkan oleh Yayan (pendeta) yang menyesuaikan jadwal kebaktian jika bentrok dengan kegiatan Seren Taun. Demikian pula yang dilakukan oleh kelompok masyarakat Katolik di Cigugur yang ikut terlibat aktif dalam rangkaian kegiatan Seren Taun. Kondisi yang hampir serupa juga terjadi pada lembaga keagamaan Islam, walau secara kelembagaan tidak terlibat dan melibatkan diri dalam kegiatan Seren Taun, namun secara pribadi tokohnya selalu menghadiri undangan pada kegiatan Seren Taun. Selain itu, keterlibatan secara individu dalam berbagai kegiatan di tengah masyarakat menjadi bukti bagaimana proses penyesuaian diri terjadi di tengah masyarakat.

Uraian tersebut menunjukkan bahwa untuk memahami proses penyesuaian diri yang dilakukan oleh kelompok masyarakat minoritas dengan lingkungan budaya setempat yang mayoritas dilakukan melalui proses yang menurut Bruner: "Saya harus menyesuaikan diri sesuai dengan apa yang mereka inginkan". ${ }^{14}$ Proses penyesuaian diri masyarakat pada kelompok kebudayaan dominan didasarkan pada tiga komponen besar yang secara sosiologis relevan untuk menggambarkan etnik di tengah situasi yang multi-etnis, yaitu: (1) komponen rasio kependudukan dan tidak sekedar fakta terdapatnya keberagaman etnik, (2) keajegan budaya lokal dan cara anggota kelompok lain berhubungan serta berartikulasi dengannya, dan (3) pemusatan kekuatan dan penyebarannya diantara penduduk yang berasal dari etnik

\footnotetext{
13 Parsudi Suparlan, "Menuju Masyarakat Indonesia yang Multikultural". Antropologi Indonesia 69 tahun, 2002.

14 E.M. Bruner, The Expression of Ethnicity in Indonesia, dalam Cohen, A. Urban Ethnicity. London: Tavistock Publications, 1974, h.255.
} 
lainnya yang beragam. ${ }^{15}$

Melihat fakta yang terjadi dalam kehidupan bermasyarakat di kawasan Cigugur, tampak bahwa konformitas terjadi di tengah masyarakat. Mereka tidak memandang perbedaan keyakinan sebagai suatu masalah yang dapat memecah belah, karena bagi mereka kebersamaan dalam menjalani kehidupan adalah hal yang utama. Proses ini jelas tidak mudah, karena mereka harus mengesampingkan ego masing-masing dan menganggap diri paling benar. Menganggap ajaran yang diyakininya sebagai sesuatu yang paling benar dan harus dipaksakan kepada orang lain. Semua proses yang terjadi di tangah masyarakat Cigugur dilembagakan di tengah masyarakat, walaupun sifatnya tidak formal. Hal ini sesuai dengan apa yang disampaikan oleh Parsons bahwa "Sepanjang... konformitas terhadap standar orientasi nilai memenuhi kedua kriteria tersebut, artinya dari titik pandang siapa saja yang bertindak pada sistem tersebut, yaitu bentuk pemenuhan kebutuhannya sendiri dan optimis terhadap reaksi orang lain yang bertindak tersebut, maka standar tersebut dapat dikatakan melembaga". ${ }^{16}$

Sistem sosial yang terjadi di tengah masyarakat Cigugur memenuhi persyaratan fungsional menurut Parsons yang disingkat menjadi A-G-I-L, yaitu Adaptation (adaptasi atau menyesuaikan diri), Goal Attainment (pencapaian tujuan), Integration (integrasi), dan Latent Pattern Maintenance (mempertahankan pola). ${ }^{17}$ Semua proses AGIL tersebut terjadi pada masyarakat Cigugur, bagaimana mereka beradaptasi dengan lingkungan budaya yang ada, bagaimana mereka berupaya mencapai tujuan bersama, bagaimana mereka mengintegrasikan diri serta bagaimana mereka mempertahankan pola yang ada dan menyebarluaskannya di tengah masyarakat serta mewariskannya kepada generasi penerus.

Kemajemukan keagamaan di antara masyarakat Cigugur dianggap sebagai hukum Tuhan (sunnatullah), sehingga agama atau kepercayaan kepada Tuhan tidak boleh dipaksakan kepada siapapun. Semua orang berhak memilih apa yang menjadi pegangan

\footnotetext{
15 Ibid.

16 Johnson, Teori Sosiologi: Klasik dan Modern terj. R.M.Z. Lawang dari Sociological Theory, 1990, h. 124.

17 Ritzer dan Goodman, Teori Sosiologi Modern, Jakarta: Prenada, 2011.
}

hidupnya. Keadaan ini berlanjut pada tingkat mikro yaitu dalam sistem keluarga, dapat terjadi perbedaan agama. Seperti pak Didi yang mempunyai anggota keluarga beragam agamanya. Pak Didi sendiri merupakan penghayat terhadap Tuhan Yang Maha Esa memiliki seorang kakak yang beragama Islam dan dua adik yang beragama Katholik. Keberagaman ini tidak hanya terjadi dalam lingkungan masyarakat kebanyakan, keluarga pemangku adat di Cigugur bahkan memiliki keturunan yang beragama berbeda. Ada yang beragama Islam, Kristen Katholik, Kristen Protestan, dan penghayat terhadap Tuhan Yang Maha Esa atau ADS atau Sunda Wiwitan.

Menghadapi realitas kemajemukan agama dan sikap umat terhadap agamanya, Komaruddin Hidayat membedakan tipologi sikap berkeagamaan menjadi lima. Pertama, sikap ekslusifisme yang melahirkan pandangan bahwa ajaran yang paling benar hanyalah agama yang dipeluknya. Agama lain sesat dan harus dikikis atau pemeluknya dikonvensi, baik agama maupun pemeluknya terkutuk dalam pandangan Tuhan. Kedua, sikap inklusifisme yang berpandangan bahwa di luar agama yang dipeluknya juga terdapat kebenaran meskipun tidak seutuhnya atau tidak sesempurna agama yang dianutnya. Di sini masih didapatkan toleransi teologis dan iman. Ketiga, pluralisme yang cenderung lebih moderat lagi, berpandangan bahwa secara teologis, pluralisme agama dipandang sebagai suatu realitas yang masing-masing berdiri sejajar sehingga semangat misionaris atau dakwah tidak relevan. Keempat, ekletivisme adalah suatu sikap keberagaman yang berusaha mencocok untuk dirinya sehingga format akhir dari sebuah agama menjadi semacam mosaik yang bersifat eklektik. Kelima, universalisme yang beranggapan bahwa dasar agama adalah satu dan sama. ${ }^{18}$ Masyarakat Cigugur menganggap bahwa setiap agama bermuara pada Tuhan yang sama. Perdamaian di antara mereka tidak tercipta jika masyarakat menganut sikap eksklusif dan saling mengkafirkan antaranggota masyarakat.

Berbeda dengan daerah lainnya di Indonesia, keberagaman dalam masyarakat Cigugur tidak pernah menimbulkan konflik yang berarti. Isu

18 Andito, Atas Nama Agama, Wacana Agama Dalam Dialog Bebas Konflik, Bandung: Pustaka Hidayah, 1998, h. 119. 
sara yang menjadi penyulut api perpecahan tak pernah terlihat. Masyarakat hidup dengan sikap toleransi yang mengesampingkan kepentingan pribadi dan golongan. Masyarakat saling menghargai satu sama lain. Puncak dari kebersamaan ini adalah perdamaian. Perdamaian yang terjadi merupakan hasil dari pola adaptasi masyarakat dalam menyesuaikan diri dengan kebudayaan. Masyarakat selalu bersikap conform sehingga perilaku menyimpang dan tindakan kriminal menjadi sangat rendah.

Konsep internalisasi dan institusionalisasi sangat penting karena hanya internalisasi nilainilai yang melembaga maka integrasi perilaku motivasional murni terjadi pada struktur sosial, sehingga lapisan motivasi yang "lebih dalam" menjadi berguna bagi pemenuhan harapan peran. Berkaitan dengan hal tersebut, internalisasi menunjuk pada sistem kepribadian, institusionalisasi menunjuk pada sistem sosial. Jika komitmen nilai yang diinternalisasi individu secara konsisten menghasilkan tindakan yang memenuhi harapan orang lain dan mereka memberikan persetujuan, maka nilai seperti itu dan tindakan yang diakibatkannya itu melembaga.

Parsons mengidentifikasi empat struktur institusional yang perlu ada pada kelompok masyarakat. Pertama, struktur kekerabatan, yakni struktur yang berhubungan dengan pengaturan ungkapan seksual, pemeliharaan, dan pendidikan generasi muda. Kedua, struktur prestasi instrumental dan stratifikasi, yakni struktur yang menyalurkan semangat pendorong individu dalam memenuhi tugas yang perlu untuk mempertahankan kesejahteraan seluruh masyarakat sesuai dengan nilai yang dianut bersama. Strategi pokok untuk menjamin motivasi ini, adalah pemberian penghargaan kepada orang sesuai dengan sumbangannya. Ketiga, teritorialitas, kekuatan, dan integrasi dalam sistem kekuasaan. Semua masyarakat harus memiliki bentuk organisasi teritorial. Tujuannya untuk mengontrol konflik internal dan untuk berhubungan dengan masyarakat lainnya atau masyarakat memiliki bentuk organisasi politik. Keempat, agama dan integrasi nilai. Bahwa masalah pembatasan nilai dan komitmen kuat terhadap nilai sangat erat hubungannya dengan institusi agama. Secara tradisional, agama memberi kerangka arti simbolis yang bersifat umum yang karenanya sistem nilai masyarakat memperoleh makna akhir atau mutlak. Artinya, kepercayaan dasar serta sentimen secara khas dibentuk oleh warisan agama. ${ }^{19}$

Sistem sosial terdiri dari sejumlah aktoraktor individual yang saling berinteraksi dalam situasi yang sekurang-kurangnya memiliki aspek lingkungan atau fisik, aktor-aktor yang memiliki motivasi dalam arti mempunyai kecenderungan untuk mengoptimalkan kepuasan, yang hubunganya dengan situasi mereka didefinisikan dan dimediasi dalam term sistem simbol bersama yang terstruktur secara kultural. ${ }^{20}$

Keteraturan sosial menurut Parsons akan terbentuk jika memenuhi beberapa tahap. Pertama, sejumlah mekanisme pengendalian sosial dapat digunakan untuk mendorong ke arah penyesuaian. Kedua, sistem sosial harus mampu menghargai perbedaan, bahkan penyimpangan tertentu yang berskala kecil. Ketiga, sistem sosial harus memberikan berbagai peluang untuk berperan yang memungkinkan berbagai macam kepribadian dapat mengungkapkan diri mereka sendiri tanpa mengancam integrasi sistem. ${ }^{21}$ Sosialisasi dan kontrol sosial adalah alat untuk mempertahankan keseimbangan sistem sosial. Perlu sebuah akomodasi bentuk-bentuk individualitas dan penyimpangan, bentuk yang lebih ekstrim dari penyimpangan harus ditangani dengan konsep penyeimbangan ulang (requilibrating) karena masyarakat adalah sistem sosial yang sangat penting.

Kulturadalah kekuatan utama yang mengikat sistem tindakan. Kultur menengahi interaksi antaraktor, menginteraksikan kepribadian, dan menyatukan sistem sosial. Aspek-aspek sistem kultural tersedia bagi sistem sistem sosial dan sistem personalitas, tetapi tidak menjadi bagian dari sistem itu. Personalitas diartikan sebagai sistem orientasi dan motivasi tindakan aktor individual yang terorganisir. Disposisi kebutuhan berasal dari dorongan hati yang dibentuk lingkungan sosial. Citra aktor menjadi sangat pasif karna dia dikendalikan dorongan hati atau sistem kultural.

\footnotetext{
19 D.P. Johnson, Teori Sosiologi: Klasik dan Modern terj. R.M.Z. Lawang dari Sociological Theory, Jakarta: Gramedia, 1990, h.126.

20 Ritzer dan Goodman, Teori Sosiologi Modern, Jakarta: Prenada, 2011, Hal. 124.

21 Ibid h. 126.
} 


\section{Penutup}

\section{Kesimpulan}

Masyarakat Indonesia yang Bhinneka Tunggal Ika tidak sekedar keanekaragaman suku bangsa dan kebudayaannya, melainkan keanekaragaman kebudayaan yang ada dalam masyarakat Indonesia. Sebagai negara yang memiliki corak kebudayaan beragam, konflik horizontal dan vertikal seringkali terjadi pada masyarakat. Isu SARA seringkali menyulut konflik dan api perpecahan hingga pertumpahan darah. Padahal kemajemukan keagamaan di antara umat manusia tidak terelakkan lagi, bahkan kemajemukan ini telah merupakan hukum Tuhan (sunnatullâh), sehingga agama atau kepercayaan kepada Tuhan tidak boleh dipaksakan kepada siapapun. Semua orang berhak untuk memilih apa yang menjadi pegangan hidupnya.

Masyarakat Cigugur merupakan masyarakat yang multi agama namun kehidupan mereka seolah tidak ada konflik. Kedamaian dan kebersamaan begitu terasa mewarnai kehidupan mereka yang beragam keyakinan. Gotong royong dan kerja sama tetap terjalin dalam keseharian tanpa melihat perbedaan yang terjadi di antara mereka. Kesemuanya itu didasarkan atas dasar persamaan hak sebagai warga dan rasa saling menghormati serta saling menghargai atas setiap perbedaan.

Masyarakat membentuk pola toleransi antarumatberagamayangsangatkuat.Masyarakat lebih mengedepankan unsur persaudaraan dibandingkan kepentingan pribadinya sebagai pemeluk agama. Dalam perayaan Seren Taun misalnya, masyarakat bahu membahu dan bekerja sama dalam mensukseskan acara. Tanpa memandang perbedaan agama, masyarakat larut dengan perayaan pesta panen yang telah dilaksanakan berpuluh tahun lalu. Bentuk kebersamaan yang lainnya adalah masyarakat dengan suka rela menolong tetangganya yang sedang mengadakan hajat tertentu. Semua itu dilakukan tanpa pamrih demi menegakkan rasa persaudaraan mereka sesama masyarakat Cigugur meski mereka saling berbeda keyakinan.

Pada kasus masyarakat Cigugur tampak bahwa ikatan darah atau kekeluargaan mempunyai jangkauan solidaritas yang tinggi dibanding keyakinan keagamaan. Hal ini tampak dari diabaikannya perbedaan keyakinan keagamaan dalam menjalani kehidupan sosial kemasyarakatan. Hukum pertemanan, prinsip solidaritas, saling bantu, saling merasakan, dan sebagainya, hal inilah yang menjadi inti dari hubungan kekeluargaan. Semangat kekeluargaan adalah semangat nilai hubungan sosial antara sesama anggota keluarga, semangat persaudaraan, solidaritas antara sesama kerabat, semangat kolektivisme, dan semangat komunalisme. Sikap saling menghargai terhadap kebudayaan yang didukung oleh masyarakat lain, di mana masing-masing mengakui kelemahankelemahannya, kelebihan-kelebihannya, akan mendekatkan masyarakat-masyarakat yang menjadi pendukung kebudayaan-kebudayaan tersebut.

Melihat fakta yang terjadi dalam kehidupan bermasyarakat di kawasan Cigugur, tampak bahwa konformitas terjadi di tengah masyarakat. Mereka tidak memandang perbedaan keyakinan sebagai suatu masalah yang dapat memecah belah, karena bagi mereka kebersamaan dalam menjalani kehidupan adalah hal yang utama. Masing-masing pemeluk agama menganggap bahwa adat-istiadat lebih utama dibandingkan prinsip keagamaan yang mengikat. Tokoh masing-masing agama menjadi pemersatu dengan membaur bersama tokoh adat yang di Cigugur, Pangeran Djatikusumah. Tokoh masing-masing agama ini menjadikan budaya setempat tetap lestari. Keberadaan tokoh agama dalam berbagai kegiatan yang melibatkan masyarakat merupakan hal yang penting karena merupakan simbol keagamaan dan menggambarkan kebersamaan di tengah keberagaman.

\section{Implikasi}

Penelitian ini diharapkan dapat memberikan implikasi bagi berbagai pihak, khususnya penentu kebijakan. Implikasi tersebut adalah sebagai berikut:

a. Sebagai pembelajaran bagi masyarakat, umumnya masyarakat Indonesia, yang juga sekaligus bisa dijadikan wilayah percontohan bagi wilayah lainnya di Indonesia yang multi etnis, budaya, suku bangsa, dan agama, serta mengeliminir terjadinya konflik.

b. Sebagai salah satu wilayah swasta di 
provinsi Jawa Barat, khususnya wilayah Kabupaten Kuningan yang tentunya memiliki daya tarik tersendiri. Ke depan bisa saja wilayah tersebut bisa menjadi salah satu "Wilayah Wisata Kesatuan dalam Keragaman".

\section{Saran}

Berdasarkan kesimpulan dan implikasi di atas, maka saran dari peneliti kepada Pemerintah Daerah Cigugur Kabupaten Kuningan Provinsi Jawa Barat adalah sebagai berikut:

a. Harus ada dukungan dari pemerintah daerah setempat, terutama untuk mempermudah berbagai akses, baik berupa akses informasi seperti peta dan akses transportasi yang memadai.

b. Harus ada dukungan dari pemerintah daerah setempat untuk membuatkan buku sejarah resmi mengenai sejarah dan kondisi masyarakat Cigugur, terutama yang berkaitan dengan Agama Djawa Sunda (ADS) sebagai panduan "Wisata Budaya" wilayah Cigugur, Kabupaten Kuningan, Provinsi Jawa Barat.

\section{Daftar Pustaka}

Adiwikarta, S. Sosiologi Pendidikan: Isu dan Hipotesis tentang Hubungan Pendidikan dengan Masyarakat. Jakarta: PPLPTK Dirjen Dikti, Depdikbud. 1988.

Andito. Atas Nama Agama, Wacana Agama Dalam Dialog Bebas Konflik. Bandung: Pustaka Hidayah. 1998.

Arikunto, Suharsini. Prosedur Penelitian. Yogyakarta: Bumi Aksara. 2002.

Azra, Azyumardi. Toleransi Agama dalam masyarakat Majemuk: Perspektif Muslim Indonesia dalam Elza Peldi Taher. Merayakan kebebasan beragama, Bunga Rampai 70 Tahun Djohan Effendi.
Jakarta: Yayasan Abad Demokrasi. 2011.

Bruner, E.M. The Expression of Ethnicity in Indonesia, dalam Cohen, A. Urban Ethnicity. London: Tavistock Publications. 1974.

Bungin, Burhan. Penelitian Kualitatif. Jakarta: Kencana. 2009.

Hefner, Robert W. Introduction: Multiculturalism and Citizenship in Malaysia, Singapore, and Indonesia dalam The Politic of Multiculturalism: Pluralism and Citizenship in Malaysia, Singapore, and Indonesia. Hawai: University of Hawai'i Press. 2001.

Johnson, D.P. Teori Sosiologi: Klasik dan Modern terj. R.M.Z. Lawang dari Sociological Theory. Jakarta: Gramedia. 1990.

Koentjaraningrat. Metode-metode Penelitian Masyarakat, Edisi ke-III. Jakarta: Grafindo Pustaka Utama. 1997.

Muhajir, Noeng. Metode Penelitian Kualitatif. Yogyakarta: Rake Saresin. 1996.

Ritzer, George dan Goodman. Teori Sosiologi Modern. Jakarta: Prenada. 2011.

Soekanto, Soerjono. Sosiologi Suatu Pengantar. Jakarta: Rajawali Press. 2006.

Sugiyono. Metode Penelitian Pendidikan Pendekatan Kuantitatif, Kualitatif, R\&D, Bandung: Alfabeta. 2006.

\section{Artikel dan Makalah}

Arkanudin. Hubungan Sosial dalam Masyarakat dalam bttp://prof-arkan.blogspot.com/ 2012/04/ bubungan-sosial-dalam-masyarakat. html. [22-11-2012]

Djatikusumah. Artikel Pemaparan Budaya Spiritual Paguyuban Adat Karubun Urang, Cigugur Kuningan Jawa Barat. 1995.

Djatikusumah. Artikel berjudul "Cagar Budaya Nasional Gedung Paseban Tri Panca Tunggal (Cigugur Kuningan Jawa Barat)”. 1997.

Suparlan, Parsudi. Menuju Masyarakat Indonesia yang Multikultural. Antropologi Indonesia 69 tabun. 2002. 